\title{
Peningkatan Kualitas Pembelajaran Guru Melalui Model dan Media Pembelajaran bagi Generasi Z
}

\author{
Ratri Kusumaningtyas, Ina Mar'atus Sholehah, Nika Kholifah \\ Fakultas Komunikasi dan Informatika Universitas Muhammadiyah Surakarta \\ Email: rk122@ums.ac.id
}

\section{Article Info}

Submitted: 26 Oktober 2019

Revised: 14 November 2019

Accepted: 7 Desember 2019

Published: 7 Januari 2020

Keywords: learning model, learning media, education
Kata kunci: model pembelajaran, media pembelajaran, pendidikan

\begin{abstract}
Generation $Z$ is a generation that has a different character from previous generations. Therefore training is needed for teachers or educators in order to develop learning in accordance with their characteristics. The purpose of this activity is to improve the ability of teachers to prepare models and learning media that are interesting and in accordance with the characteristics of Generation $Z$ students. This activity was attended by representatives of the Muhammadiyah Branch Managers in the field of Education. especially those who work as educators from elementary / MI to high school / vocational school at PCM Gatak. For schools managed by PCM Kec. Gatak needs to increase the ability and skills of teachers / educators in the learning process. This activity is divided into 2 sessions: first, material explanation and second, sharing and discussion. The output target of this activity is to increase the knowledge of educators at PCM Gatak, especially in terms of using models and learning media. The result of this activity is an increase in teacher understanding oflearning models such as: inquiry based learning, problem based learning, experiential based learning, task based learning, theme based learning, cooperative learning, project based learning and flipped classroom models. These models can be used as an appropriate alternative in teaching generation Z. The use of technology-based learning media can be adjusted to the learning needs. In addition, there is a need for further devotion focusing on simulating learning models using effective and efficient learning media
\end{abstract}
Abstrak
Generasi Z merupakan generasi yang memiliki karakter berbeda dari generasi sebelumnya, yaitu multitasking, artinya mereka dapat melakukan beberapa pekerjaan dalam satu waktu. Sehingga perlu adanya peningkatan kemampuan dan keterampilan guru atau tenaga pendidik dalam proses pembelajaran agar dapat sesuai dengan karakteristik siswa generasi Z. Tujuan kegiatan ini adalah untuk meningkatkan kemampuan guru dalam menyiapkan model dan media 
pembelajaran yang menarik dan sesuai dengan karakteristik siswa generasi Z, yaitu generasi yang lahir di tahun 1995-2000. Kegiatan diikuti oleh perwakilan dari Pimpinan Cabang Muhammadiyah (PCM) bidang Pendidikan, khususnya Pendidik jenjang SD/MI hingga SMA/ SMK di PCM Gatak. Kegiatan dibagi menjadi 2 sesi, yaitu sesi pertama berisi penjelasan materi dan sesi kedua berisi tentang diskusi dan berbagi pengalaman. Target luaran dari kegiatan ini adalah peningkatan kompetensi para pendidik di PCM Gatak dalam penggunaan model dan media pembelajaran. Setelah dilakukan kegiatan, para guru memperoleh wawasan dan pemahaman guru tentang berbagai model pembelajaran, seperti: inquiry based learning, problem based learning, experiential based learning, task based learning, theme based learning, cooperative learning, project based learning dan flipped classroom model. Model pembelajaran seperti inilah yang dapat digunakan sebagai alternatif dalam mendidik atau mengajar generasi Z. Pemanfaatan media pembelajaran berbasis teknologi dapat disesuaikan dengan kebutuhan pembelajaran. Selain itu perlu adanya pengabdian lanjutan berfokus pada simulasi model pembelajaran dengan menggunakan media pembelajaran yang efektif dan efisien

\section{PENDAHULUAN}

Muhammadiyah sebagai salah satu organisasi Islam terbesar di Indonesia, memiliki tujuan menegakkan dan menjunjung tinggi agama Islam sehingga terwujud masyarakat Islam yang sebenar-benarnya. Sebagai organisasi yang memfokuskan gerakannya pada gerakan dakwah amar ma'ruf nahi munkar, maka kualitas dakwah dan pendidikan adalah tujuan penting yang ingin dicapai. Selain itu Muhammadiyah juga dapat dipahami sebagai suatu gerakan untuk memurnikan ajaran Islam (Tahang, 2019).

Sebagai organisasi yang memerlukan penyesuaian terhadap globalisasi dan tantangan zaman, revitalisasi cabang dan ranting menjadi salah satu prioritas program yang harus dilaksanakan. Hal ini sesuai dengan hasil Muktamar Muhammadiyah ke-46 di Yogyakarta. Pengembangan secara kuantitatif dilaksanakan melalui pembentukan cabang dan ranting baru. Selain itu pengembangan secara kualitatif dilakukan dengan menghidupkan kembali kepengurusan cabang dan ranting yang tidak aktif, serta mengaktifkan kembali yang belum aktif (LPCR, 2010).

Dalam struktur organisasi Muhammadiyah, ranting adalah kesatuan anggota dalam satu tempat atau kawasan. adapun Cabang adalah kesatuan ranting dalam satu tempat (PP
Muhammadiyah, 2010). Upaya untuk penguatan cabang dan ranting salah satunya dapat dilakukan dengan meningkatkan sumber daya manusia pengelolanya. Pimpinan Cabang Muhammadiyah Kecamatan Gatak merupakan salah satu cabang Muhammadiyah di kabupaten Sukoharjo yang memiliki puluhan amal usaha berupa rumah sakit, klinik kesehatan, sekolah dari tingkat dasar hingga menengah. PCM kecamatan Gatak mengelola kurang lebih 6 Madrasah Ibtidaiyah Muhammadiyah dengan jumlah guru sebanyak 65 orang dan jumlah siswa sebanyak 830 orang. Selain itu, PCM kecamatan Gatak juga mengelola 2 Sekolah Menengah Pertama dengan jumlah guru 33 orang dan siswa 178 orang. Saat ini, PCM Gatak juga berhasil mengelola sebuah Sekolah Menengah Atas dengan jumlah guru 18 orang dan mempunyai 248 siswa. Banyaknya sekolah dari berbagai tingkat yang dikelola oleh PCM Gatak, membuat fokus peningkatan sumber daya PCM di bidang pendidikan menjadi sangat penting untuk dilakukan.

Arus informasi dan perkembangan teknologi yang begitu pesat dalam kurun waktu 10 tahun terakhir membawa perubahan di berbagai bidang, termasuk bidang pendidikan. seperti yang kita ketahui, akhir-akhir ini banyak berkembang diskursus tentang klasifikasi generasi. Generasi merupakan suatu konstruksi 
sosial, didalamnya terdapat sekelompok orang dengan kesamaan usia dan pengalaman historis. Individu merupakan bagian dari suatu generasi tertentu jika mereka lahir pada tahun yang sama, dalam rentang waktu 20 tahun serta ada dalam suatu dimensi sosial dan sejarah yang sama. Perbedaan antar generasi kadang menjadi penyebab utama masalah pekerjaan dan kehidupan bersama, entah dalam hal motivasi, perilaku konsumerisme, pengambilan keputusan, dan sebagainya (Rachmawati, 2019)

Generasi X yang merupakan generasi yang lahir pada tahun-tahun awal perkembangan teknologi dan informasi, seperti penggunaan PC (Personal Computer), video games, TV kabel dan internet. Ciri-ciri generasi ini diantaranya mudah beradaptasi, mampu menerima perubahan dengan baik, tangguh, mandiri dan loyal, mengutamakan citra, ketenaran, uang, tipe pekerja keras, menghitung kontribusi yang diberikan perusahaan terhadap kinerjanya (Rachmawati, 2019)

Generasi $Y$ atau generasi millennial, merupakan generasi dengan penggunaan teknologi komunikasi instan yang lebih intens, seperti email, sms, instant messaging dan media sosial (facebook \& Twitter). Dapat dikatakan bahwa generasi $\mathrm{Y}$ merupakan generasi yang tumbuh di era internet booming. Istilah ini pertama kali dipakai di Amerika Serikat pada tahun 1993 (Hidayatullah, 2018)

Sedangkan penelitian Bencsik, Csikos, dan Juhez (2016) mengungkapkan bahwa generasi yang lahir antara tahun 1995-2010 secara umum memiliki kesamaan dengan generasi $\mathrm{Y}$, namun generasi $\mathrm{Z}$ lebih multitasking atau mampu mengaplikasikan seluruh kegiatan dalam satu waktu. Kegiatan multitasking tersebut contohnya, menggunakan media sosial melalui ponsel, melakukan pencarian data dengan menggunakan PC, dan mendengarkan musik dengan headset dalam satu waktu yang sama. Kegiatan-kegiatan yang dilakukan pada umumnya berhubungan dengan dunia maya, hal ini tidak mengherankan, sebab sejak kecil mereka sudah mengenal teknologi dan terbiasa dengan gadget canggih yang secara tidak langsung berpengaruh terhadap kepribadian. Diprediksi puncak kesuksesan generasi $\mathrm{Z}$ adalah pada tahun 2045, itulah mengapa mempelajari kebiasaan, karakteristik dan perilaku mereka menjadi hal yang sangat penting (Rahayu, 2019). Dengan memahami karakter siswa yang diajar oleh para guru yang saat ini mayoritas merupakan generasi Z, perlu dipahami bahwa mereka dilingkupi oleh informasi yang berlimpah dan terbiasa dalam penggunaan gadget. Melihat kenyataan tersebut, maka peran guru harus disesuaikan dengan kondisi yang ada. Guru tidak lagi hanya sebagai sumber, namun juga harus bertindak sebagai fasilitator (Narulita, 2019).

Berdasarkan pengelompokan kategori generasi di atas, dapat diperkirakan bahwa para guru atau tenaga pendidik di PCM Gatak yang notabene mengajar siswa jenjang MI, SMP dan SMA yang merupakan kategori generasi Z. Dari data Biro Pusat Statistik (2017), diperoleh informasi bahwa populasi generasi $\mathrm{Z}$ berada pada usia aktif sekolah, baik pada tingkat Sekolah Dasar (SD) maupun tingkat pendidikan tinggi (Universitas dan sejenisnya) itu sangat besar. Hal ini tentu perlu dijadikan perhatian bagi guru/ tenaga pendidik yang notabene berbeda generasi dengan peserta didiknya. Karena perbedaan generasi dapat menjadikan perbedaan dalam cara berkomunikasi hingga dalam cara penggunaan teknologi, sehingga membutuhkan penyesuaian dari pihak guru/ tenaga pendidik dalam menjembatani perbedaan dengan peserta didiknya.

Dalam menghadapi tantangan mengajar generasi Z, para guru/tenaga pendidik PCM Gatak dituntut untuk lebih kreatif dalam mengembangkan mediad dan proses pembelajaran yang sesuai bagi generasi tersebut. Diperlukan suatu model dan media pembelajaran yang tepat agar siswa tidak mudah merasa bosan, apalagi generasi $\mathrm{Z}$ lebih suka menggunakan internet atau biasa disebut dengan istilah "googling" dalam menemukan dan mencari pemecahan suatu masalah termasuk dalam kegiatan belajar-mengajar di kelas.

Perihal media pembelajaran, sebenarnya termasuk dalam salah satu tugas utama guru dalam rangka mendesain atau merancang sebuah pembelajaran yang bermakna bagi anak didik agar mereka termotivasi untuk menambah pengetahuan, kecakapan, dan karakter mereka (Ariwibowo, 2018). Guru/tenaga pendidik harus dapat mendesain kegiatan pembelajaran 
agar menjadi lebih menyenangkan, sesuai dengan kebutuhan dan perkembangan zaman.

Melihat karakter generasi $\mathrm{Z}$ yang multitasking atau terbiasa dengan teknologi, maka perlu adanya penyampaian materi mengenai model dan media pembelajaran yang sesuai dengan karakter generasi Z, diantaranya: inquiry based learning, problem based learning, experiential based learning, task based learning, theme based learning, cooperative learning, project based learning dan flipped classroom model. Sedangkan penggunaan media dapat dipilih dan disesuaikan dengan kebutuhan dan model pembelajaran yang akan digunakan.

Berdasarkan permasalahan mitra yang telah teridentifikasi, diketahui bahwa diperlukan suatu terobosan dalam pengajaran untuk menghadapi generasi Z, mengingat karakter guru dengan siswa generasi $\mathrm{Z}$ berbeda. Oleh karena itu realisasi pemecahan dari permasalahan tersebut adalah dengan memberikan materi model dan media pembelajaran bagi generasi Z. Melalui materi tersebut, guru tidak hanya memperoleh gambaran mengenai karakter para peserta didiknya, namun juga dapat menentukan pembelajaran yang tepat bagi mereka. Selain itu guru dapat membuat siasat model pembelajaran yang dapat menarik minat dan lebih mudah dipahami oleh peserta didik. Melalui pemberian materi tersebut, guru dapat merancang metode pembelajaran dan menerapkannya dalam proses belajar mengajar di kelas, serta memanfaatkan media pembelajaran yang sesuai dengan karakter peserta didik.

\section{METODE}

Sebelum pelatihan dilaksanakan, diadakan tahap persiapan dengan melakukan penentuan peserta pelatihan, identifikasi masalah sasaran, serta perencanaan konseptual mengenai pelatihan yang diberikan kepada peserta. selain itu juga dilakukan penentuan waktu dan tempat pelaksanaan, serta melakukan koordinasi dengan pihak-pihak yang terlibat dalam kegiatan. Dalam kegiatan ini 2 orang mahasiswa dilibatkan untuk membantu terlaksananya kegiatan, mulai dari perencanaan hingga pelaksanaan kegiatan seperti melakukan dokumentasi.

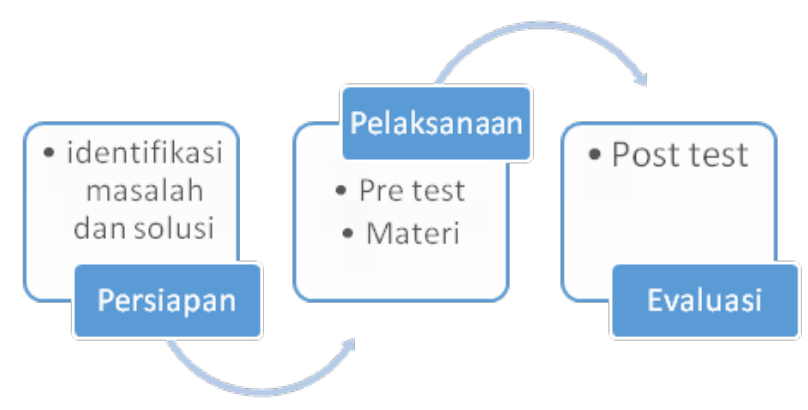

Gambar 1. Tahapan Kegiatan

Pengabdian ini menggunakan model ceramah dan diskusi. Kegiatan dibagi dalam beberapa sesi yakni pre test, pemberian materi dan sesi diskusi \& tanya jawab, kemudian post test.

a. Pre test berupa pemberian form yang berisi pertanyaan - pertanyaan yang harus dijawab oleh para peserta terkait pengetahuan mereka mengenai model dan media pembelajaran.

b. Penyampaian materi berupa pengenalan mengenai generasi $\mathrm{Z}$ dan karakteristiknya.

c. Sesi tanya jawab dan diskusi mengenai model dan media pembelajaran yang pernah dilakukan oleh para guru di PCM Kec. Gatak, serta berbagai kesulitan mengajar yang pernah dihadapi.

d. Pemberian materi berupa model dan media pembelajaran yang sesuai dengan kebutuhan generasi $\mathrm{Z}$.

e. Post test berupa pemberian form yang berisi pertanyaan - pertanyaan yang harus dijawab peserta setelah memperoleh materi pengabdian.

\section{HASIL DAN PEMBAHASAN}

Kegiatan pengabdian dilaksanakan pada hari Jumat, 20 April 2018, di laboratorium Komputer Program Studi Informatika Universitas Muhammadiyah Surakarta. kegiatan ini diikuti oleh 20 peserta yang merupakan guru dan kepala sekolah di bawah naungan PCM kecamatan Gatak.

Guru atau tenaga pendidik merupakan faktor penting yang menentukan mutu pendidikan Indonesia. Tanpa pengembangan wawasan, guru akan tertinggal, apalagi generasi 
sekarang membutuhkan pemanfaatan teknologi dalam kegiatan pembelajarannya. Perbedaan karakter antara peserta didik dan pendidik (guru) juga menjadi faktor penting untuk mempertimbangkan jenis metode pembelajaran dan penggunaan media yang sesuai, sehingga diharapkan kegiatan belajar mengajar dapat berlangsung tepat sasaran, membantu terserapnya materi dan mampu mencapai target yang diharapkan. Melalui pelatihan ini memberikan beberapa materi terkait upaya mengembangkan metode pembelajaran dan pemanfaatan media pembelajaran bagi siswa. Gambar 1 merupakan suasana ketika pelaksana menjelaskan materi.

Secara umum kegiatan berlangsung sesuai dengan tahapan yang sudah direncanakan. Kegiatan dimulai dengan pembukaan, kemudian dilanjutkan dengan pre test, kemudian pemberian materi. Pada sesi berikutnya diadakan sesi tanya jawab terkait materi dan pengalaman peserta mengenai proses pembelajaran. Adapun materi pelatihan yang diberikan terkait dengan model dan media pembelajaran yang tepat bagi generasi Z.

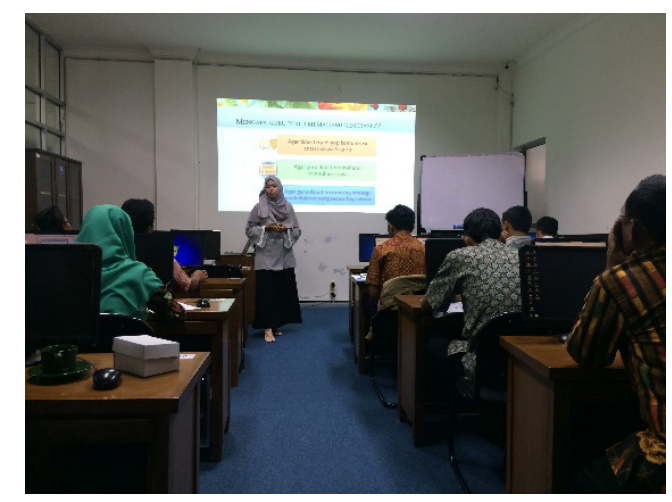

Gambar 2. Penyampaian materi

Setelah pemberian post test, diadakan kuis berhadiah dengan memberikan pertanyaan terkait dengan materi. Bagi peserta yang menjawab dengan paling cepat dan tepat, diberikan hadiah menarik. Setelah kuis, diikuti dengan menyimpulkan materi kegiatan kemudian dilanjutkan dengan acara penutup. Para peserta terlihat begitu antusias dalam mengikuti kegiatan, hal ini ditunjukkan dengan respon yang diberikan selama kegiatan. Berdasarkan tanya jawab dan diskusi dapat diketahui bahwa: a. Peserta bahkan belum pernah mendengar beberapa jenis model pembelajaran yang disampaikan, istilah generasi $\mathrm{Z}$ memang familiar bagi peserta, namun mereka belum memahami dan cenderung menyamakannya dengan generasi millennial yang notabene berbeda dari generasi $\mathrm{Z}$.

b. Kesulitan-kesulitan yang sering dihadapi oleh peserta dalam mengajar diantaranya: siswa sulit berkonsentrasi untuk menyimak materi yang disampaikan dalam waktu lama, siswa cepat bosan dengan model pembelajaran yang monoton. Hal ini membuat materi pembelajaran tidak tersampaikan secara efektif.

c. Dalam kegiatan pembelajaran, umumnya para guru juga belum memaksimalkan penggunaan media pembelajaran di kelas, sebagian besar karena keterbatasan sarana, sebagian ada juga karena alas an tidak terbiasa menggunakan media pembelajaran

Setelah diberikan materi berupa model dan media pembelajaran, para peserta mendapatkan gambaran mengenai metode pembelajaran yang tepat, banyak dari mereka yang ingin mencoba model dan pemanfaatan media pembelajaran dengan lebih maksimal, sesuai dengan kebutuhan para siswanya. Beberapa peserta juga mengungkapkan bahwa mereka pernah mencoba beberapa model pembelajaran, namun belum konsisten. Selain itu mereka juga memerlukan waktu untuk merancang dan menyesuaikan materi dengan metode yang akan digunakan di kelas. Selain itu para peserta juga tertarik untuk membandingkan hasil evaluasi pembelajaran yang menggunakan model yang berbeda, sehingga mereka dapat mempertimbangkan model apa yang sekiranya tepat untuk meningkatkan pemahaman dan prestasi para siswa.

Selama proses pelatihan, ada juga feedback dari peserta. beberapa menyampaikan masalah yang dapat dijadikan sebagai saran bagi kegiatan pengabdian berikutnya, diantaranya mengenai penggunaan media belajar yang seringkali terkendala faktor biaya dari pihak siswa. Hal ini mungkin dapat menjadi tindak lanjut agar kegiatan pengabdian berikutnya dapat mencarikan solusi bagi permasalahan tersebut. 


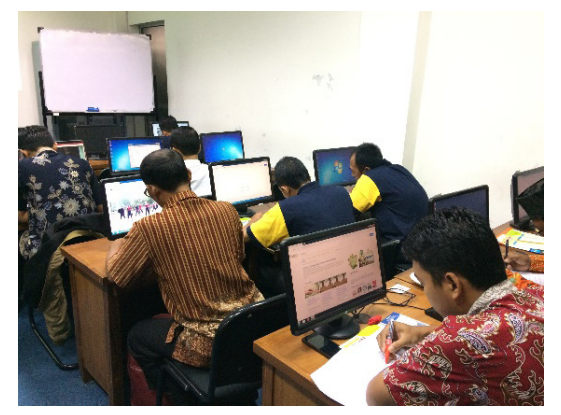

Gambar 3. Para peserta mengikuti kegiatan dengan antusias

Persoalan lain diungkapkan oleh salah seorang guru yang mengajar mata pelajaran seni, dimana ia merasa kesulitan dalam mengajar dikarenakan kelas yang diajar merupakan kelas besar, atau kelas dengan jumlah siswa yang cukup banyak yaitu sekitar 40 siswa. Bagi guru mata pelajaran seni jumlah siswa yang terlalu banyak dalam satu kelas membuat kegiatan belajar menjadi kurang efektif. Persoalan ini mungkin dapat dijadikan masukan bagi pihak sekolah maupun pihak-pihak yang akan melakukan pengabdian agar dapat menyiasati dengan pemberian pelatihan bagi metode dan media pembelajaran berikutnya.

Banyak dari peserta menginginkan dilaksanakannya pelatihan lanjutan agar lebih memperdalam lagi materi terkait dan dapat dilakukan praktek untuk merancang model dan media yang tepatyang dapatlangsung diterapkan. Para peserta merasa bahwa perancangan pembelajaran yang efektif dan efisien bagi generasi sekarang harus dioptimalkan. Diharapkan luaran dari kegiatan berikutnya dapat berupa model yang telah selesai dirancang dan dapat mereka praktekkan di kelas. Selain itu perlu adanya modul yang dibagikan kepada para peserta didik sebagai panduan penerapan model pembelajaran, karena di dalam penelitian ini masih terbatas pada penyampaian pengetahuan dan pemberian materi, sedangkan para peserta hanya diberikan materi berupa print out dari materi yang disampaikan dalam pengabdian. Perlu juga dibentuk tim pelatihan khusus bagi para pendidik agar lebih matang dalam menerapkan model dan media pembelajaran yang sesuai bagi generasi $\mathrm{Z}$.

Berdasarkan evaluasi pelaksanaan kegiatan, materi yang disajikan dapat diterima dan dipahami dengan baik oleh peserta. Beberapa peserta merasa beberapa model pembelajaran yang dibahas dalam pengabdian dapat langsung mereka praktekkan di kelas, diantaranya inquiry based learning, problem based learning, experiential based learning, task based learning, theme based learning, serta cooperative learning. Menurut para peserta, dalam menerapkan model-model tersebut tidak memerlukan terlalu banyak penyesuaian dan persiapan yang terlalu lama. Sedangkan beberapa peserta masih ragu dalam menerapkan flipped classroom model dan project based learning, hal ini dikarenakan peserta didik merasa masih belum dapat sepenuhnya menerapkan model pembelajaran tersebut pada peserta didik. Hal ini mempertimbangkan media dan sumber daya yang dimiliki peserta didik, serta kedua model tersebut membutuhkan persiapan yang matang serta kesiapan dari kemapuan peserta didik.

Ada beberapa faktor penghambat dan pendukung dari kegiatan ini sehingga dapat berjalan dengan baik. Faktor pendukungnya antara lain: adanya dukungan dari fakultas yang dapat memfasilitasi tempat pelaksanaan kegiatan, kerjasama yang baik dari PCM Kec Gatak, serta antusiasme para peserta yang hadir. Adapun penghambatnya di sini adalah keterbatasan waktu sehingga masing-masing peserta kurang mendapatkan kesempatan dalam membuat rancangan dan mempraktekkan metode pembelajaran yang disampaikan. Selain itu peserta juga tidak dapat mempraktekkan satu-persatu penggunaan media pembelajaran. Selain itu belum adanya modul pembelajaran sebagai panduan bagi peserta didik juga belum disediakan. Untuk pengabdian berikutnya diharapkan ada modul yang diberikan kepada peserta. Adapun feedback dari peserta dapat dilihat pada tabel 1 .

Dari pemberian materi yang dilakukan, dilihat pula peningkatan kognisi dari peserta pelatihan melalui pemberian pre test dan post test. Dari 20 peserta, ada 17 orang yang mengisi pre test dan post test dengan lengkap, sehingga data yang diambil hanya 17 orang. Adapun hasil skor pre test dan post test dapat dilihat pada tabel 2 .

Setelah diuji perbedaan rata-rata 2 kelompok berpasangan (dependent) parametric dengan Excel, didapatkan hasil yang disajikan pada Tabel 3.

Warta LPM, Vol. 23, No. 1, Maret 2020 
Tabel 1. Feedback Peserta

\begin{tabular}{|c|c|c|}
\hline Permasalahan & Tanggapan & Saran \\
\hline $\begin{array}{l}\text { Peserta belum pernah } \\
\text { mendengar beberapa jenis } \\
\text { model pembelajaran yang } \\
\text { disampaikan, dan belum } \\
\text { familiar dengan generasi Z }\end{array}$ & $\begin{array}{l}\text { Peserta merasa setuju dengan apa yang } \\
\text { disampaikan, bahwa generasi yang } \\
\text { berbeda menuntut perbedaan dalam } \\
\text { model pembelajaran, peserta merasakan } \\
\text { adanya gap dengan generasi Z. }\end{array}$ & $\begin{array}{l}\text { Perlu ada sosialisasi lanjutan } \\
\text { terkait perbedaan antar } \\
\text { generasi serta karakternya, } \\
\text { terutama terkait kepentingan } \\
\text { pembelajaran }\end{array}$ \\
\hline \multirow[t]{2}{*}{$\begin{array}{l}\text { Peserta sering mengalami } \\
\text { kesulitan dalam mengajar } \\
\text { generasi Z.. }\end{array}$} & $\begin{array}{l}\text { Beberapa peserta mengeluhkan } \\
\text { sulitnya mengajar generasi sekarang. } \\
\text { Mereka mengeluhkan siswa sulit } \\
\text { berkonsentrasi untuk menyimak } \\
\text { materi yang disampaikan dalam waktu } \\
\text { lama, siswa cepat bosan dengan model } \\
\text { pembelajaran yang monoton. Hal ini } \\
\text { membuat materi pembelajaran tidak } \\
\text { tersampaikan secara efektif. }\end{array}$ & $\begin{array}{l}\text { Guru perlu menerapkan model } \\
\text { pembelajaran sebagaimana } \\
\text { yang disampaikan dalam } \\
\text { kegiatan pengabdian, dimana } \\
\text { model-model tersebut sesuai } \\
\text { dengan karakter generasi Z. }\end{array}$ \\
\hline & $\begin{array}{l}\text { Selain itu keluhan juga datang dari } \\
\text { peserta yang mengajar di kelas dengan } \\
\text { jumlah siswa yang banyak yakni lebih } \\
\text { dari } 40 \text { siswa. Hal ini membuat proses } \\
\text { pembelajaran menjadi tidak efektif }\end{array}$ & $\begin{array}{l}\text { Perlu adanya pembicaraan } \\
\text { dengan pihak terkait, yakni } \\
\text { sekolah mengenai jumlah siswa } \\
\text { dalam satu kelas, agar proses } \\
\text { pembelajaran lebih efektif. }\end{array}$ \\
\hline $\begin{array}{l}\text { Dalam kegiatan } \\
\text { pembelajaran, umumnya } \\
\text { para guru juga belum } \\
\text { memaksimalkan } \\
\text { penggunaan media } \\
\text { pembelajaran di kelas, }\end{array}$ & $\begin{array}{l}\text { Menurut peserta, media yang mereka } \\
\text { gunakan masih terbatas, karena belum } \\
\text { memanfaatkan media dengan efektif } \\
\text { dan efisien karena belum merancang } \\
\text { pembelajaran yang memanfaatkan } \\
\text { media. }\end{array}$ & $\begin{array}{l}\text { Perlu adanya pengabdian } \\
\text { lanjutan terkait praktek } \\
\text { penggunaan media dalam } \\
\text { pembelajaran. }\end{array}$ \\
\hline
\end{tabular}

Tabel 2. Skor pre test dan post test

\begin{tabular}{ccc}
\hline No. & Pre Test & Post Test \\
\hline 1 & 37 & 39 \\
2 & 37 & 40 \\
3 & 37 & 42 \\
4 & 41 & 39 \\
5 & 42 & 47 \\
6 & 42 & 46 \\
7 & 39 & 40 \\
8 & 38 & 38 \\
9 & 38 & 37 \\
10 & 37 & 46 \\
11 & 36 & 43 \\
12 & 37 & 41 \\
13 & 39 & 43 \\
14 & 36 & 43 \\
15 & 39 & 44 \\
16 & 41 & 43 \\
17 & 42 & 41 \\
\hline
\end{tabular}

Tabel 3. t-Test: Paired Two Sample for Means

\begin{tabular}{lrr}
\hline & Pre Test & Post Test \\
\hline Mean & 38,70588 & 41,88235 \\
Variance & 4,595588 & 8,360294 \\
Observations & 17 & 17 \\
Pearson Correlation & 0,266315 & \\
Hypothesized Mean & 0 \\
Difference & \multicolumn{2}{|}{16} \\
Df & $-4,21509$ \\
t Stat & 0,000329 \\
P(T<=t) one-tail & 1,745884 \\
t Critical one-tail & 0,000657 \\
P(T<=t) two-tail & \\
t Critical two-tail & 2,119905 & \\
\hline
\end{tabular}

Dari tabel 3, diperoleh informasi bahwa nilai rata-rata pre test, sebelum diberikan materi yaitu 38,70588 . Sedangkan setelah pemberian 
materi nilai rata-rata menjadi 41,88235 sehingga ada peningkatan secara deskriptif. Ho dalam penelitian ini yaitu tidak ada perbedaan signifikan antara sebelum dan sesudah pemberian materi pengabdian. Sedangkan h1: ada perbedaan yang signifikan antara sebelum dan sesudah pemberian materi pengabdian.

Hasilnya $t$ table yaitu 2,119905 dengan $p$ value sebesar 0,000657 . Oleh karena $p$ value $<0,05$ (taraf signifikansi 5\%). Maka dapat disimpulkan bahwa $\mathrm{H}_{0}$ ditolak, maka $\mathrm{H}_{1}$ diterima, sehingga ada perbedaan yang signifikan antara sebelum dan sesudah pemberian materi kegiatan.

\section{SIMPULAN}

Dari kegiatan pengabdian yang telah dilakukan, metode-metode pembelajaran seperti: inquiry based learning, problem based learning, experiential based learning, task based learning, theme based learning, cooperative learning, project based learning dan flipped classroom model, dapat dijadikan sebagai alternatif yang tepat dalam mengajar generasi $\mathrm{Z}$.

Pemanfaatan media pembelajaran yang berbasis teknologi yang dapat disesuaikan dengan kebutuhan pembelajaran, hal yang perlu diperhatikan adalah karakteristik generasi $\mathrm{Z}$ yang menyukai penggunaan simbol dan gambar serta pengoptimalan penggunaan teknologi untuk mendukung proses pembelajaran yang tepat dan efisien. Berdasarkan hasil pre test dan post test terdapat peningkatan pengetahuan setelah pemberian materi, sehingga hasil post test lebih baik dari hasil post test, dan perbedaannya cukup signifikan. Adapun saran bagi kegiatan pengabdian selanjutnya, harus diadakan penguatan yang lebih difokuskan pada simulasi model pembelajaran dan praktek menggunakan media pembelajaran yang efektif dan efisien.

\section{PERSANTUNAN}

Dalam kesempatan ini, saya selaku pelaksana pengabdian ingin mengucapkan terima kasih kepada Universitas Muhammadiyah Surakarta, yang membuat pengabdian ini dapat terlaksana, serta Pihak Fakultas Komunikasi dan Informatika yang telah memfasilitasi dan menyediakan tempat bagi berlangsungnya kegiatan pengabdian ini.

Kami juga mengucapkan terimaksih kepada para Guru di bawah naungan PCM Gatak yang berpartisipasi dalam mengikuti kegiatan pengabdian dari awal hingga selesai.

\section{REFERENSI}

Anita Titu, Maria. 2015. Penerapan Model Pembelajaran Project Based Learning (PJBL) Untuk Meningkatkan Kreativitas Siswa Pada Materi Konsep Masalah Ekonomi. Prosiding Seminar Nasional.

Aribowo, Eric Kunto. 2018. Digitalisasi Aksara Jawa dan Pemanfaatannya Sebagai Media Pembelajaran Bagi Musyawarah Guru Mata Pelajaran Bahasa Jawa SMP Kabupaten Klaten. Jurnal WARTA LPM, Vol. 21, No. 1, Maret 2018

Bencsik, A., Csikos, G., \& Juhaz, T. 2016. Y and Z Generations at Workplaces. Journal of Competitiveness, 8(3), 90-106. https://doi.org/10.7441/joc.2016.03.06

Biro Pusat Statistik, 2015, Retrieved from Persentase Penduduk Usia 7-24 Tahun Menurut Jenis Kelamin, Kelompok Umur Sekolah, dan Partisipasi Sekolah 1, 2002-2016: https://www.bps. go.id/linkTabelStatis/vie w/id/1533

Hidayatullah, Syarif dkk. 2018. Perilaku Generasi Milenium Dalam Menggunakan Aplikasi Go-Food. Jurnal Manajemen dan Kewirausahaan. Vol. 6, No. 2

LPCR. 2010. lpcr.muhammadiyah.or.id.

Narulita, et al. 2019. Pengembangan Kompetensi Guru Dalam Pembelajaran PAI Bagi Generasi Z. Jurnal Publikan. Vo. 9, No. 3 
Kusumaningtyas, dkk - Peningkatan Kualitas Pembelajaran Guru ...

Nurdyansyah, dkk. 2016. Inovasi Model Pembelajaran. Sidoarjo: Nizamia Learning Center.

Ozkan, M., \& Solmaz, B., 2015, Mobile Addiction of Generation Z and Its Effects. Procedia - Social and Behavioral Sciences, 205, 92-98.

Rachmawati, Dewi. 2019. Welcoming Gen Z in Job World (Selamat Datang Generasi Z di dunia kerja). Proceeding Indonesia Career Center Network Summit IV.

Rahayu, 2019. Widayati. Pembelajaran Sejarah Untuk Generasi Z. JPSI. Vol. 2, No. 1

Susana, T., 2012. Kesetiaan pada panggilan di era digital. Jurnal Orientasi Baru. 21, 1, 55-78.

Tahang, H., Wekke, I. S., \& Fatimah, F. 2019. Dakwah Muhammadiyah Melalui Lembaga Pendidikan. 